\title{
Production and levels of foliar nitrogen in rocket salad fertilized with controlled-release nitrogen fertilizers and urea
}

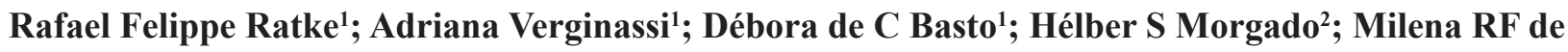 \\ Souza $^{1}$; Eliana Paula Fernandes ${ }^{1}$ \\ 1UFG, C. Postal 131, 74001-970 Goiânia-GO; rfratke@gmail.com; driverginassi@gmail.com; deboracarvalho85@hotmail.com; milena. \\ rizzia@bol.com.br; elianafernades@agro.ufg.br; ${ }^{2}$ IFGoiano, C. Postal 51,76300-000 Ceres-GO; helber@globo.com
}

\begin{abstract}
Controlled-release nitrogen fertilizers enhance crop productivity and decrease nitrogen loss through volatilization and leaching. This study aimed at determining the effect of nitrogen treatments provided by controlled-release nitrogen fertilizers and urea. The following fertilizers were tested: 1 (agricultural urea), 2 (ammonium sulfonitrate + nitrification inhibitor, dimethylpyrazole phosphate $\left(\right.$ Entec $\left.\left.26^{\circledR}\right)\right), 3$ (urea + Kimberlit polymer $\left(\right.$ Kimcoat $\left.^{\circledR}\right)$ ) and 4 (urea + NBPT (Super $\mathrm{N}$ - Agrotain $\left.^{\circledR}\right)$ ). Treatments corresponded to 0, 100, 200, 400 and 800 $\mathrm{kg} \mathrm{ha}^{-1}$ of $\mathrm{N}$ with rocket salad grown inside a greenhouse, assessing the production of fresh and dry leaf mass as well as levels of foliar nitrogen. Doses of different controlled-release nitrogen fertilizers showed significant polynomial regressions for the production of rocket salad fresh leaf mass and levels of foliar nitrogen, whereby Entec $26^{\circledR}$ did not show significant polynomial regression, considering the last parameter evaluated. The production of rocket salad dry leaf mass did not display significant linear regressions. The maximal production of rocket salad fresh leaf mass was reached at doses of $600,490,765$, and $462 \mathrm{~kg} \mathrm{ha}^{-1}$ of $\mathrm{N}$ with the use of urea, Entec $26^{\circledR}$, Kimcoat $\mathrm{N}^{\circledR}$ and Super $\mathrm{N}^{\circledR}$, respectively.
\end{abstract}

Keywords: Eruca sativa, coated urea, urease inhibitor.

\section{RESUMO}

Produção e teor de nitrogênio foliar em rúcula adubada com fertilizantes nitrogenados de liberação lenta e uréia

Os fertilizantes nitrogenados de liberação lenta aumentam a produtividade das culturas e diminuem as perdas de nitrogênio por volatilização e lixiviação. O objetivo deste trabalho foi determinar, no cultivo de rúcula, o efeito de doses de $\mathrm{N}$ fornecidas por fertilizantes nitrogenados de liberação lenta e pela uréia. Testaram-se os fertilizantes: 1 (uréia agrícola), 2 (sulfonitrato de amônio + inibidor de nitrificação Dimetil Pirazol Fosfato (Entec $\left.26^{\circledR}\right)$ ), 3 (uréia + polímero Kimberlit (kimcoat $\left.\mathrm{N}^{\circledR}\right)$ ) e 4 (uréia + NBPT $\left(\right.$ Super N - Agrotain $\left.^{\circledR}\right)$ ), e as doses de 0,100, 200, 400 e $800 \mathrm{~kg} \mathrm{ha}^{-1}$ de $\mathrm{N}$ em rúcula crescidas em casa de vegetação, avaliando-se a produtividade de matéria fresca de folhas, matéria seca de folhas e os teores de nitrogênio foliar. As doses de diferentes fertilizantes nitrogenados de liberação lenta mostraram regressões polinomiais significativas para a produção de matéria fresca de folhas de rúcula e teores de nitrogênio foliar, sendo que neste ultimo parâmetro avaliado, o Entec $26^{\circledR}$ não obteve regressão polinomial significativa. A produção de matéria seca de folhas de rúcula mostrou regressões lineares não significativas. As máximas produções de matéria fresca de folhas de rúcula foram obtidas com as doses de $600 \mathrm{~kg} \mathrm{ha}^{-1} ; 490 \mathrm{~kg} \mathrm{ha}^{-1} ; 765 \mathrm{~kg} \mathrm{ha}^{-1} \mathrm{e} 462 \mathrm{~kg} \mathrm{ha}^{-1}$ de $\mathrm{N}$ com o uso de uréia, Entec $26^{\circledR}$, Kimcoat $\mathrm{N}^{\circledR}$ e Super $\mathrm{N}^{\circledR}$, respectivamente.

Palavras-chave: Eruca sativa, uréia revestida, inibidor de urease.

(Recebido para publicação em 30 de dezembro de 2009; aceito em 12 de abril de 2011)

(Received on December 30, 2009; accepted on April 12, 2011)

$\mathrm{R}$ ocket salad (Eruca sativa L.) is an annual herbaceous plant of the family Brassicaceae. It is a leafy vegetable, rich in protein, vitamins $\mathrm{A}$ and $\mathrm{C}$, omega 3 fatty acids, mineral salts, calcium, iron, sulfur and potassium (Filgueira, 2003). Vegetables require high quantities of nutrients in a short time, thereby being nutritionally demanding (Coutinho et al., 1993). Because it is a leafy vegetable, the fertilizing of rocket salad with $\mathrm{N}$ is very important for it to produce leaves of good quality, stimulating the vegetative development of the plant, which in turn promotes greater gain of dry mass and leaf area (Cavarianni et al., 2008).

The supply of $\mathrm{N}$ can occur with organic or mineral sources, where urea is the main source of $\mathrm{N}$ in nitrogen fertilizers (Almeida et al., 2007). N is a component of a large number of compounds in the plant, where it has an important role in plant physiology and the quality of leafy vegetables, mainly with respect to its effect on the level of nitrate in the product (Coelho, 2002).

The correct management of $\mathrm{N}$ is essential for increasing the efficiency of its use. Nitrogen is an element that is easily lost by leaching, volatilization and denitrification in the soil-plant system. Thus, the proper management of nitrogen fertilizing has been a major problem. Therefore, it is necessary to determine the most appropriate method of application, because this affects the behavior of $\mathrm{N}$ in the soil and its efficiency for the crops. One of the alternatives for increasing its efficiency is to divide the recommended dose, which leads to a significant increase in operational costs. However, the utilization of sources that show a slow or controlled release of the nutrients is an option (Lezana \& Carrasco, 2002).

Fertilizers with controlled release can be classified as slow- or controlled- 
release fertilizers and stabilized fertilizers. Slow-release fertilizers show low solubility in relation to a reference soluble source. Stabilized fertilizers contain additives to increase the time of their availability in the soil (Cantarella \& Marcelino, 2008).

Entec $26^{\circledR}$ is a fertilizer with release of about four months, containing $26 \% \mathrm{~N}$, where $7.5 \%$ is in the form of $\mathrm{NO}_{3}^{-}$and $18.5 \%$ in the form of $\mathrm{NH}_{4}^{+}$, and $13 \%$ $\mathrm{S}$, covered with wax (Mendonca et al., 2007). Kimcoat $N^{\circledR}$ is a urea covered with three layers of high-charge density polymer (Roberto, 2007).

The available inhibitors are classified as reagents that interact with sulfhydryl groups, hydroxamates and structural analogs of urea, which inhibit the action of urease, competing for the active site of the enzyme. This last group includes NBPT [N-(n-butyl)], which is an additive that protects the urea applied on the surface from degradation and loss by volatilization of ammonia. NBPT inhibits the enzymatic degradation of urea by the action of urease, for a period of 10 to 14 days, where it is later degraded into its constituent elements, N, P and S (Cantarella \& Marcelino, 2008). The commercial formulation Super N contains $20 \%$ to $25 \%$ NBPT (Scivittaro et al. 2005).

The aim of this study was to determine the production of rocket salad and the effect of doses of $\mathrm{N}$ contained in controlled-release nitrogen fertilizers Entec $26^{\circledR}$, Kimcoat $\mathrm{N}^{\circledR}$ and Super $\mathrm{N}$ $\left(\right.$ Agrotain $^{\circledR}$ ) compared to the response obtained with the application of urea.

\section{MATERIAL AND METHODS}

The study was conducted in a greenhouse of the Agronomie School and Food Engineering of the Universidade Federal de Goias (UFG), in the spring of 2008. The soil utilized for cultivation of rocket salad in pots was characterized as eutrophic Red Latosol (Oxisoil). Chemical analysis of the soil presented: $\mathrm{pH}=5.1 ; \mathrm{H}+\mathrm{Al}=3.1 \mathrm{cmol} \mathrm{dm}^{-3} ; \mathrm{Ca}=$ $3.3 \mathrm{cmol} \mathrm{dm}^{-3} ; \mathrm{Mg}=0.7 \mathrm{cmol} \mathrm{dm}^{-3} ; \mathrm{P}=$ $4.20 \mathrm{mg} \mathrm{dm}^{-3} ; \mathrm{K}=0.14 \mathrm{cmol}_{\mathrm{c}} \mathrm{dm}^{-3}$; sum

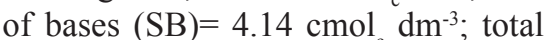
cations exchange capacity $(\mathrm{CTCtotal})=$
$7.24 \mathrm{cmol}_{\mathrm{c}} \mathrm{dm}^{-3}$; bases saturation $(\mathrm{V})=$ $57.2 \%$; organic matter $(\mathrm{MO})=1.9 \%$.

A completely randomized experimental design with a factorial scheme of $4 \times 5$ ( 4 sources and 5 doses) and three repetitions was used. The nitrogen fertilizers utilized were: 1 (agricultural urea), 2 (ammonium sulfonitrate + nitrification inhibitor dimethylpyrazol phosphate (Entec $\left.26^{\circledR}\right)$ ), 3 (urea + Kimberlit polymer (Kimcoat $\mathrm{N}^{\circledR}$ )) and 4 (urea + NBPT $\left(\right.$ Super N - $\left.\operatorname{Agrotain}^{\circledR}\right)$ ), at doses of 0 , $100,200,400$ and $800 \mathrm{~kg} \mathrm{ha}^{-1}$ of nitrogen in the cultivation of rocket salad (Eruca sativa). Rocket salad was planted at three equidistant points in the pots with a capacity of $2 \mathrm{~kg}$ of soil, with an inside diameter of $18.5 \mathrm{~cm}$. The seedlings were thinned out at 15 days after seeding (DAS), allowing the growth of one plant per pot. Nitrogen fertilizers were added to the soil at $20 \mathrm{DAS}$. Irrigation of rocket salad was done with the addition of 250 $\mathrm{mL}$ of water/pot daily.

The rocket salad plants were collect at 40 DAS. At this step, the leaves were separated from the roots, in order to characterize the commercial part. Immediately after the collection, the fresh mass of the leaves (MFF) was determined. After drying in a forced-air oven at $60^{\circ} \mathrm{C}$ for $32 \mathrm{~h}$, the dry leaf mass (MSF) was measured. Finally, nitrogen was determined in samples of the dried, ground and digested leaves of rocket salads, utilizing the distillation-titration method for total $\mathrm{N}$ in plants described by Silva (2009).

The results of the progressive increase in concentration of different nitrogen fertilizers were submitted to analysis of variance and to polynomial and linear regressions using the statistics software SAS (Statistical Analysis System Institute, 1999).

\section{RESULTS AND DISCUSSION}

The different doses of controlledrelease nitrogen fertilizers and of urea utilized did not significantly affect the production of fresh leaf mass (MFF), production of dry leaf mass (MSF) or foliar levels of nitrogen (foliar N) in the cultivation of rocket salad. However, the results showed significant regressions for MFF and foliar N (Figures 1 and 3).

The productions of fresh leaf mass (MFF) for rocket salad as a function of dose of controlled-release nitrogen fertilizer and of urea showed a quadratic behavior (Figure 1). The maximal production of MFF for rocket salad was $7.98 \mathrm{~g} /$ pot, obtained at a dose of $600 \mathrm{~kg}$ ha $^{-1}$ of $\mathrm{N}$ with the use of urea. Entec $26^{\circledR}$ showed a maximal production of $8.59 \mathrm{~g} /$ pot using $490 \mathrm{~kg} \mathrm{ha}^{-1}$ of N. Kimcoat $\mathrm{N}^{\circledR}$ at a dose of $765 \mathrm{~kg} \mathrm{ha}^{-1}$ of $\mathrm{N}$ yielded a maximal production of $9.76 \mathrm{~g} /$ pot. Super $\mathrm{N}$ required a dose of $462 \mathrm{~kg} \mathrm{ha}^{-1}$ of $\mathrm{N}$ to reach a maximal production of $\mathrm{MFF}$ of $9.23 \mathrm{~g} /$ pot. Thus, the production of MFF for rocket salad was more efficient utilizing controlled-release fertilizers compared to the use of urea.

Controlled-release nitrogen fertilizers can increase crop productivity, besides reducing the application of $\mathrm{N}$, divided in this crop, and loss of nitrogen by lixiviation and volatilization (Cantarella \& Marcelino, 2008). Therefore, the efficiency of the use of controlled-release fertilizers lies in its utilization in a single application and the reduction of nitrogen dose applied to obtain maximal productivity. The increase in production of rocket salad through nitrogen fertilizing was also demonstrated by Linhares et al. (2008), who utilized as fertilizer sources cattle manure and scarlet starglory (Merremia aegyptia L.), a legume of great potential in supplying $\mathrm{N}$.

The doses of nitrogen applied to the soil, utilizing urea, Entec 26®, Kimcoat $N \otimes$ and Super $N$ as the sources, showed a linear behavior for the production of dry leaf mass (MSF) of rocket salad. However, the results for MSF showed non-significant linear regressions (Figure 2).

Zanão Junior et al. (2005) described that the production of green mass and dry mass of tsoi sum (Brassica chinensis var. parachinensis) submitted to increasing doses of nitrogen, showed significant linear regressions, utilizing ammonium sulfate as source of $\mathrm{N}$. Even though being of the same family as tsoi sum, rocket salad showed a different behavior when submitted to the different controlled-release nitrogen 


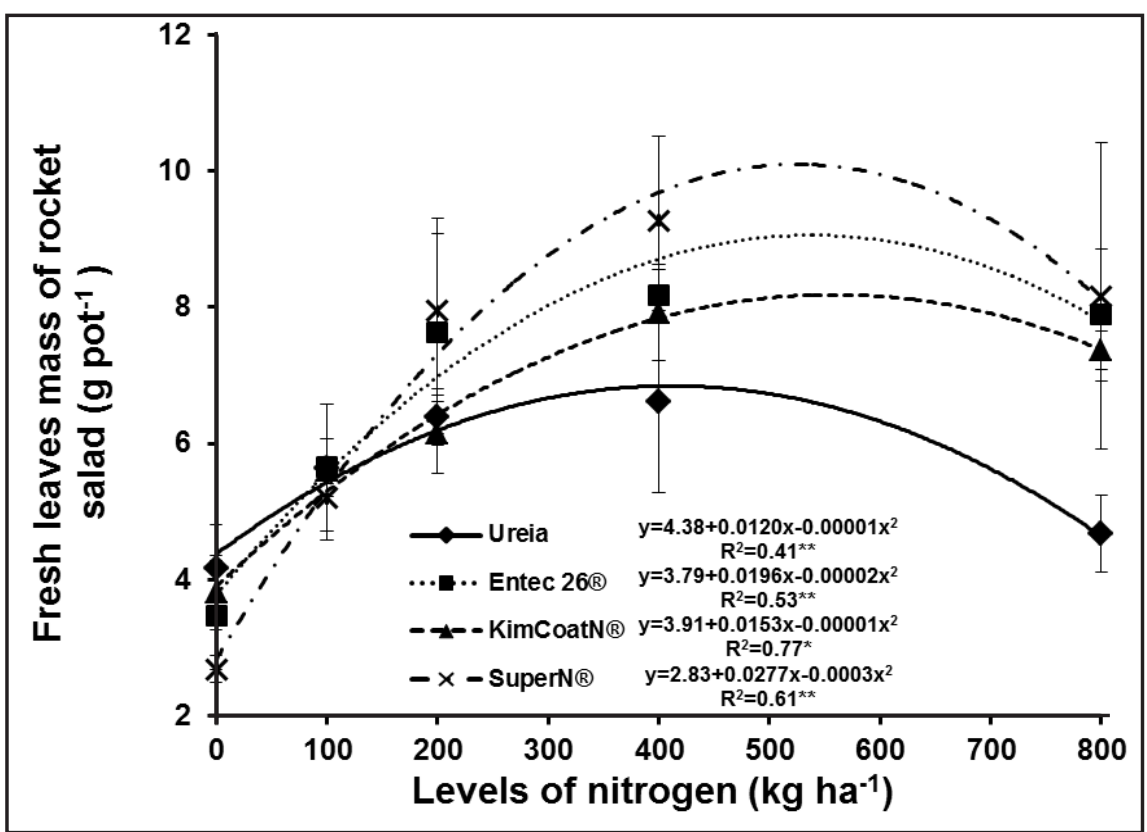

Figure 1. Polynomial regressions for the production of rocket salad fresh leaf mass making use of different controlled-release nitrogen fertilizers and urea; *significant $\mathrm{p}<0.01$, ** significant $\mathrm{p}<0.05, \mathrm{NS}=$ not significant; Bars on dots represent the mean standard error $(*$ significativo $\mathrm{p}<0,01$; **significativo $\mathrm{p}<0,05, \mathrm{NS}=$ não significativo; Barras sobre os pontos representam o erro padrão da média; regressões polinomiais para a produção de matéria fresca de folhas de rúcula utilizando diferentes fontes de fertilizantes nitrogenados de liberação lenta e uréia). Goiânia, UFG, 2008.

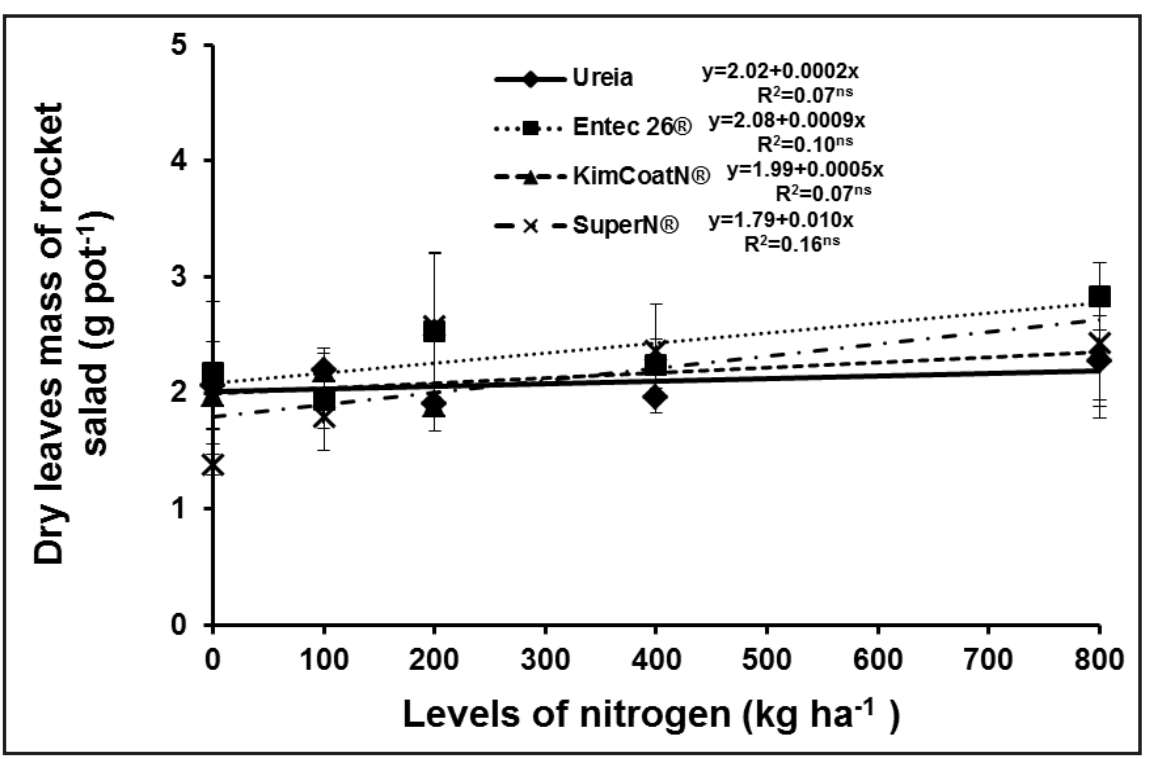

Figure 2. Polynomial regressions for the production of rocket salad dry leaf mass making use of different controlled-release nitrogen fertilizers and urea; *significant $\mathrm{p}<0.01$, ** significant $\mathrm{p}<0.05$, NS $=$ not significant; Bars on dots represent the mean standard error (regressões polinomiais para a produção de matéria seca de folhas de rúcula utilizando diferentes fontes de fertilizantes nitrogenados de liberação lenta e uréia; *significativo $\mathrm{p}<0,01$, **significativo $\mathrm{p}<0,05, \mathrm{NS}=$ não significativo; Barras sobre os pontos representam o erro padrão da média). Goiania, UFG, 2008.

fertilizers and urea. The increasing doses of $\mathrm{N}$ utilizing different $\mathrm{N}$ sources, i.e., controlled-release fertilizers and urea, the cultivation of rocket salad. Thus, the different doses and sources of $\mathrm{N}$ influenced the commercial part of the plant of rocket salad, that is, the production of leaves.

The foliar $\mathrm{N}$ levels of rocket salad showed significant polynomial regression as a function of nitrogen dose using urea, Kimcoat $\mathrm{N}^{\circledR}$ and Super $\mathrm{N}$ as the sources (Figure 3). Thus, the doses for maximal accumulation of foliar $\mathrm{N}$ for rocket salad were calculated, and the maximal foliar concentration of $\mathrm{N}$ was $40.42 \mathrm{~g} \mathrm{~kg}^{-1}$, obtained with the 1.33 $\mathrm{t} \mathrm{ha}^{-1}$ dose of urea. Rocket salad leaves showed a maximal foliar concentration of $\mathrm{N}$ of $46.32 \mathrm{~g} \mathrm{~kg}^{-1}$ with the $1.71 \mathrm{tha}^{-1}$ dose of Kimcoat $\mathrm{N}^{\circledR}$. The dose of $2.95 \mathrm{t}$ $\mathrm{ha}^{-1}$ of Super N was necessary to reach a maximal concentration of $52.23 \mathrm{~g} \mathrm{~kg}^{-1}$ of $\mathrm{N}$ in the leaves of this crop. The mean values of foliar $\mathrm{N}$ found in rocket salad leaves in this experiment were as high as $52 \mathrm{~g} \mathrm{~kg}^{-1}$. Thus, they were different than those found by Almeida et al. (2007), who reported maximal levels of 37 and $37.6 \mathrm{~g} \mathrm{~kg}^{-1}$, utilizing ground vegetables and chicken manure, respectively.

Cavarianni et al. (2004) observed an increase in the nitrogen level in rocket salad leaves with the elevation in $\mathrm{N}$ availability in the nutritious solution. Therefore, the increase in the $\mathrm{N}$ concentration in the soil due to increasing doses of $\mathrm{N}$ applied led to an increase in the concentration of $\mathrm{N}$ in the leaves of rocket salad, as observed in Figure 3. In this context, the increase in foliar $\mathrm{N}$ levels with the application of increasing doses of nitrogen were also found in the works of Cavarianni et al., (2004) and Purqueiro et al. (2007).

Total nitrogen levels in leaves of rocket salad fertilized with increasing doses of $\mathrm{N}$ utilizing Entec $26^{\circledR}$ showed non-significant polynomial regression (Figure 3). Entec $26^{\circledR}$ contains DMPP (dimethylpyrazol phosphate), which inhibits nitrification, where $\mathrm{N}$ in the soil remains in the form of ammonia for a longer period of time (Meira et al., 2009). Thus, the increasing doses of nitrogen using Entec $26^{\circledR}$ as the source provides a reduction in $\mathrm{N}$ in the form of nitrate in the soil, when compared to the zero dose. In this manner, on reducing nitrate in the soil there was an inhibition 


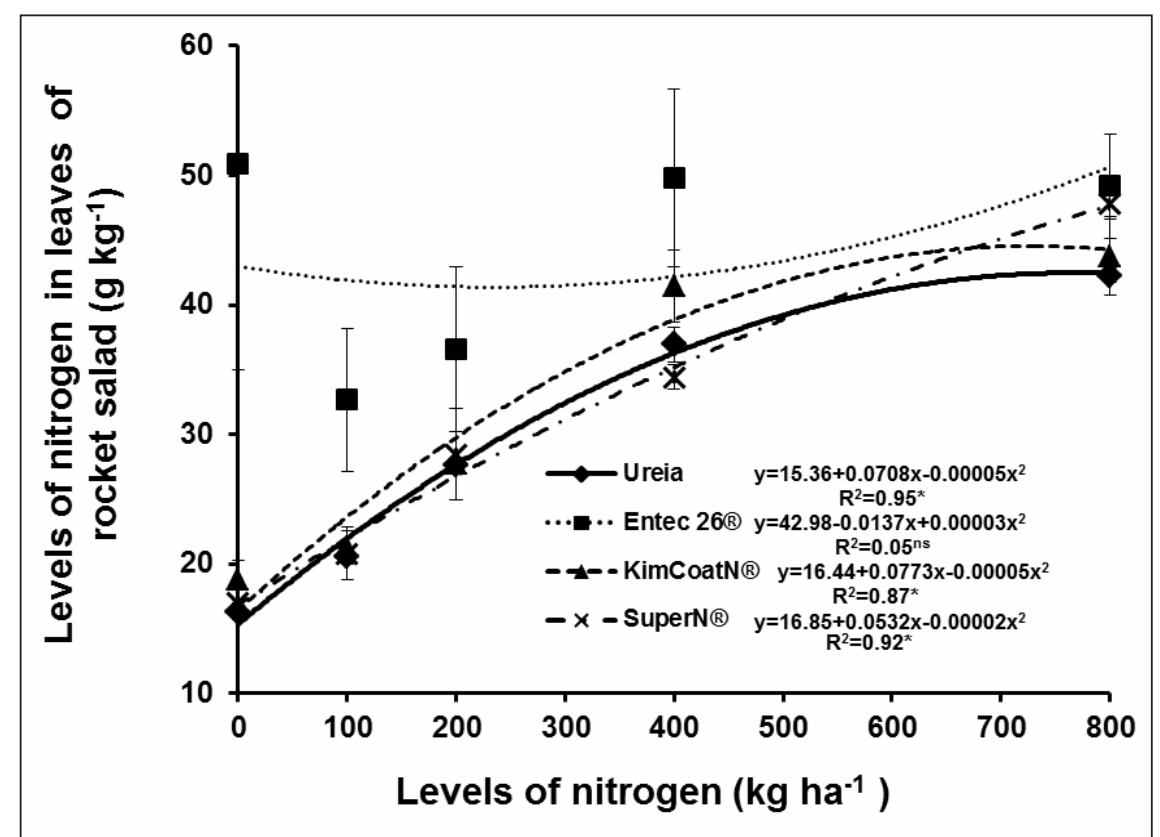

Figure 3. Polynomial regressions for nitrogen levels within rocket salad making use of different controlled-release nitrogen fertilizers and urea; *significant $\mathrm{p}<0.01, * *$ significant $\mathrm{p}<0.05$, NS $=$ not significant; Bars on dots represent the mean standard error (regressões polinomiais para teores de nitrogênio em folhas de rúcula utilizando diferentes fontes de fertilizantes nitrogenados de liberação lenta e uréia; *significativo $\mathrm{p}<0,01$; **significativo $\mathrm{p}<0,05$, NS=não significativo; Barras sobre os pontos representam o erro padrão da média). Goiânia, UFG, 2008.

of the accumulation of $\mathrm{N}$ in the leaves of rocket salad. In the soil, most of the nitrogen absorbed by the plants is in the form of nitrate (Luz et al., 2008).

\section{ACKNOWLEDGEMENTS}

We thank the Laboratory of Soils and Leaves of Universidade Federal de Goias (LASF-EA-UFG) for their support in conducting this work. We are grateful to Professor Wilson Mozena Leandro for help with statistical analysis of the results. We also thank the financial support of CAPES awarded to the first two authors of this paper.

\section{REFERENCES}

ALMEIDA MMTB; LIXA AT; SILVA EE;
AZEVEDO PHS; DE-POLLI H.2007. Avaliação da eficiência de fontes de nitrogênio para produção orgânica de rúcula: fertilizantes de leguminosas versus cama de aviário industrial. Rev. Bras. de Agroecologia 2:15881591.

CANTARELLA H; MARCELINO R. 2008. Fontes alternativas de nitrogênio para a cultura do milho. Informações Agronômicas. Piracicaba: INPI 122: 12-14.

CAVARIANNI RL; CONRADI MM; CECÍLIO FILHO AB; MAY A; CAZETTA JO. 2004. Acúmulo de nitrato em cultivares de rúcula em função da concentração de nitrogênio na solução nutritiva. In: CONGRESSO BRASILEIRO DE HORTICULTURA, 44. Resumos... Campo Grande, SOB (CD-ROM).

COELHO, RL. Acúmulo de nitrato e produtividade de cultivares de almeirão em cultivo hidropônico-NFT. 2002. Jaboticabal: UNESP-FCAV. 67p. (Tese mestrado).

COUTINHO ELM; NATALE W; SOUZA ECA. 1993. Adubos e corretivos: aspectos particulares na olericultura. In: SIMPÓSIO SOBRE NUTRIÇÃO E ADUBAÇÃO DE HORTALIÇAS. Anais....Piracicaba: POTAFÓS, p. 85-140.

FILGUEIRA, FAR. 2003. Novo manual de olericultura: Agrotecnologia moderna na produção e comercialização de hortaliças. 2ed. Viçosa: UFV, p. 412.

LEZANA JR; CARRASCO I. 2002. 3,4-dimetilpirazol fosfato (dmpp): el nuevo inhibidor de la nitrificación para fertilizantes - Experiencias en sistemas de fertirrigación. Vida Rural: 49-50.

LINHARES PCF; LIMA GKL; MADALENA JAS; MARACUJÁ PB; FENANDES PLO. 2008. Adição de jitirana ao solo no desempenho de rúcula cv. folha larga. Revista Caatinga 21:89-94.

LUZ GL; MEDEIROS SLP; MANFRON, PA; MULLER, ADAL; TORRES MG; MENTGES L. 2008. A questão do nitrato em alface hidropônica e a saúde humana. Ciência Rural 38: 2388-2394.

MEIRAFA; BUZETTI S; ANDREOTTI M; ARF O; SÁ ME; ANDRADE JAC. 2009. Fontes e épocas de aplicação do nitrogênio na cultura do milho irrigado. Semina 30:275-284.

MENDONÇA V; TOSTA MS; MACHADO JR; GOULART JÚNIOR SAR; TOSTA JS; BISCARO GA. 2007. Fertilizante de liberação lenta na formação de mudas de maracujazeiro amarelo. Ciência Agrotécnica 31:344-348.

PURQUERIO LFV; DEMANT LAR; GOTO R; VILLAS BOAS RL. 2007. Efeito da adubação nitrogenada de cobertura e do espaçamento sobre a produção de rúcula. Horticultura Brasileira 25:464-470.

ROBERTO ARJ. 2007. Kimcoat - Uma nova ferramenta para otimização do uso de fertilizantes. Informações Agronômicas. Piracicaba: INPI, 117.

STATISTICAL ANALYSIS SYSTEM INSTITUTE. SAS/STAT User's guide, version 8. Cary, NC: SAS Institute, 1999.

SCIVITTARO WB; GOMES AS; LIMA FS. 2005. Perdas de nitrogênio por volatilização de amônia em cultivo de arroz irrigado. In: CONGRESSO BRASILEIRO DE ARROZ IRRIGADO, 26. Anais....Santa Maria: SOSBAI, p. 455-458.

SILVA FC. 2009. Manual de análises químicas do solo, plantas e fertilizantes. Brasília: EMBRAPA informação tecnológica. $2^{\mathrm{a}}$ ed. p. 203 a 204.

ZANÃO JÚNIOR LA; LANA RMQ; RANAL MA. 2005. Doses de nitrogênio na produção de couve-da-Malásia. Horticultura Brasileira 23:76-80. 